\title{
Shelters for the Homeless Children: Unmasking the Plight of the Street Children in South Africa
}

\author{
Nkuna Monge Richer \\ Central China Normal University \\ E-mail:mr.nkuna@gmail.com
}

Received: May 30, 2019 Accepted: August 11, 2019 Published: August 13, 2019

doi:10.5296/ijsw.v6i2.15264 URL: https://doi.org/10.5296/ijsw.v6i2.15264

\begin{abstract}
The aim of this paper was to explore the status of the rehabilitated children in shelter homes in South Africa. The study further explored the challenges the students face in the homes as well as a critique of the sustainability of the rehabilitation framework used by the state in ensuring the children live quality and successful life after leaving the shelter homes. The study found out that despite the programme of rehabilitation of the street children in shelter homes being a noble idea, the children are facing myriad of challenges in the homes. Some of the challenges faced by the children in the homes include; lack of sufficient housing, child abuse and molestation in the children homes, lack of adequate and quality food and clothing. The main challenge facing the rehabilitation is the sustainability of the process since after the completion of education period by the children, the children are released from the homes to pave way for the admitted cohorts of children being admitted to the homes. The other challenge was lack of adequate funding by the government and civil society since the population of children to be admitted to the homes is quite huge. The study further revealed that the shelter homes were not actually offering conducive environment for the children since majority of them opt out to the streets due to oppressions or abuse by the management or fellow street children. The study recommends that the government and civil society take a pro-active approach while rehabilitating street children in shelter homes in South Africa to ensure sustainable and holistic rehabilitation
\end{abstract}

Keywords: China insurance industry, Foreign fund, Challenge

\section{Introduction}

In recent past, South Africa has been grappling with the surge of homeless families and street families. The social impacts are prevalent in the major metropolitan cities in South Africa. Despite tremendous government and non-governmental organisations' efforts of rehabilitating the street children in shelter homes, the plight of these street children in the shelter homes 
remains a thorny issue which requires sustainable social interventions. Homelessness extends beyond lacking a roof over one's head and it's explained by scholars as lack of access to socio- economic opportunities which are essential for human survival. Access to job opportunities, health services and education are among others (Makiwane, Tamasane, \& Schneider, 2010). Cultural, personal and structural are the major factors causing homelessness in South Africa.

Social exclusion which has been strongly been attributed by scholars alluded as one factor contributing to the increased homelessness in most of the cities. In South Africa the exclusion is described on political and economic view, and this implication is described as "the human community as dismembered body"(Malindi, 2014). Urban marginalization is a threat to management of cities and this leads to increased growth of informal settlements in the capital and inner cities of South Africa. This informal settlements suffer from financial constraints which lead to their children finding themselves in the streets. Being left as a street child means living one's home environment part timely or permanently and spend most of the time unsupervised on the streets as part of a subculture. In south Africa street children presents a complex issue resulting from diverse integrated factors. Political history of this country has played a big role in creating street and homeless children as agreed by most researchers(Cumber \& Tsoka-Gwegweni, 2015).

The post-apartheid aftermath resulted in so many white children moving to the streets due to prevailing worse economic status of their families. Data shows that there are approximately 9000 black street children in South Africa and there are 10,000 white children in 160 state registered and subsidized children's home. This shows a relatively high imbalance of the facts and unfortunately there are no administered homes for Africans in urban areas(Parks, Stevens, $\&$ Spence, 2007). The government and the civil-society has tried to correct this menace by establishing shelter homes and also supporting the private sector and other NGO's in setting homes where the street children are rehabilitated, fed, educated and taken care of until the age of eighteen when they are released back to the society for integration. Evidence has it that majority of those children released from children homes are not fully empowered to start life on their own and as such they finally return to the streets.

\section{Literature}

The exact number of street children in South Africa is not known but an estimate showed 10,000 street children in 2003 (Ward \& Seager, 2010), this number is expected to be larger at the resent times due to rise in economic constraints. The rise of informal settlements which are also referred to as squatter camps have also increased contributing to the rise of homelessness in the country (Hills, Meyer-Weitz, \& Asante, 2016; Parks et al., 2007). South Africa has engaged in rehabilitation activities and programmes to solve the problem of street children in the country. The failure of this programmes is due to the fact that the attempts to rescue this children from the streets is done without realistic alternatives from them (Cluver $\&$ Gardner, 2007). When providing these shelters for the children it is then important for the stakeholders to understand the background of these children and ensure effective programmes and structures are building towards rehabilitating them. Due to lost childhood many of these children have attained Pseudo- adult status.

Ward and Seager (2010), states that once an intolerable behaviour has been nurtured then for 
an individual to be pushed back into an institution and being led by a controlled life by adults to whom they must depend wholly, then their skills to survive on their own get lost along the way. Considering this factors, rushing into this shelter programmes that will merely satisfy the street children should be framed well giving a clear plan which should be holistic and comprehensive and inclusive of strategy. Non-governmental institutions in South Africa are the most effective in providing shelter programmes and services to street children (Arnold \& Rotheram-Borus, 2009). Their services are either voluntary entry and participatory or working towards prevention, reconciliation and reintegration into society (Cluver \& Gardner, 2007). The phenomenon of street children and their shelter programs is problematic. Cross, Seager, Erasmus, Ward, and O'Donovan (2010), states that the accepted conception of street children in South Africa is "Phallocentric" this is because of domination by the male experience of the street life excluding the female experience. The Child Care Acts of 1960 and 1983 was the initial form of law governing the response of street children and their rehabilitation in South Africa. This law demanded the South Africa Police to remove pickpockets and beggars from the street and deal with them accordingly. This was also a concern for the welfare of street children which led to shelters for the homeless in South Africa (Du Toit, 2010).

Homeless and street children are described as those without houses to live in. homelessness is a complex term and many people who are homeless have no shelter, access to temporary roof, informal shacks which are not safe. Those living in the street may have been their temporary or have lived for many years or permanently live there. It is evident that in South Africa not all that are homeless suffer from structural challenges. Personal issues and circumstances have also been seen to contribute to homelessness(Cross \& Seager, 2010). In a study conducted in south Africa on homeless people it showed that the top causes of homelessness were abuse and domestic violence, family problems, eviction, economic difficulties and search for independency and better life (Cross et al., 2010)

\section{Methodology}

This paper relied heavily on the literature published in various reports and fact sheets by the government agencies, civil societies and Non-Governmental organisations in charge of social welfare and protection in south Africa. To increase credibility to this information, some interviews were carried out on major stakeholders involved in the rehabilitation of the street children and homeless children in South Africa. These representative were purposefully selected from three biggest sample children homes in Durban, Kwa Zulu Natal Province where the study was carried in. The others included expert opinions from two directors of social services in the province and few selected social workers working directly in the rehabilitation projects run by the Ministry of Social Services and Home affairs. The findings were transcribed and reported thematically.

\section{Findings.}

In South Africa, Homelessness dates back from the apartheid period. Presently due to increased unemployment, lack of affordable housing, social disintegration and social economic policies have been contributors to the homeless issue in South Africa. Private spheres have been identified to provide solutions to the homelessness situation in South Africa than the political spheres. Homeless people in South Africa have no national census 
but researchers rely on individual studies which have been done in cities (Kok, Cross, \& Roux, 2010). Approximately 200,000 homeless people have been estimated in the South Africa population. In South African metropolitan municipalities, study showed that they view homelessness as a social dependency issue which should be responded by social interventions(Cumber \& Tsoka-Gwegweni, 2015).

\subsection{Causes of Homelessness of Children}

Deprivation of human basic needs is what causes homelessness. Other types of deprivation include hunger, economic insecurity and these factors are multi- faceted by the type of homelessness experienced by children. Factors that contribute to homelessness of children include; lack of affordable housing, economic insecurity, violence, health behaviours, and lack of social support, and involvement in child welfare system.

High prevalence of HIV/AIDS: HIV epidemic is a significant burden to South Africa. For the longest time now, South Africa has been grappling with the effects of high HIV prevalence. The children who were left behind as orphans with no source of live hoods have become parents. Most of their children cannot make ends meet and as such majority who were grappling with acute poverty resorted to the streets. Studies show that over $18.8 \%$ of adults in South Africa are estimated to be infected or affected with HIV-Aids and this consists of ages 15-49 who are deemed to be the most economically active cohort of population. (Seager \& Tamasane, 2010). In one of the interviews with one of the social workers in the municipal Council of Durban, the social worker alluded that HIV-Aids is one of the contributing factor for homelessness and sprouting population of street families. He said:

'Most of the children who are in the streets now either lost one or both parents as aresult of $H I V$ scourage.The government has initiated programs to have the kids rescued from the street to the shelter homes but majority would rather remain in the streets than be in the homes'.

Social worker 12, Interview on $16^{\text {th }}$ July 2918.

Concrete research has not been carried out to determine the prevalence of homeless people within the main informal settlements. It is though substantial to note that homeless community are more infected with HIV/AIDS due to their nature of lifestyle. Homelessness, unemployment and HIV infection have a complex relationship. Vulnerability of the homeless is relatively high which is due to economic and social issues. Pressure by the homeless to get daily basic needs and exposure to violence misuse of drugs and stressful situations are some of the conditions that expose this community to high risk to HIV/AIDS(Cumber \& Tsoka-Gwegweni, 2015).

Lack of affordable housing: The number of affordable units has declined over decades commensurate to the population of the cohorts of population below poverty line. Current housing policy in South Africa is based on a fundamental understanding that housing is a basic need. The right to 'have access to adequate housing, was first articulated in the ANC's Reconstruction and Development Programme (RDP) in 1994. The Central Bureau of Statistics in the population Council of South Africa indicates that the number of those applying for accommodation through the RDP programme has been on the rise (Mukorombindo, 2012). For one to be allocated a house in the RDP programme, he must be married grown-ups with a family and below the state poverty index. However, the policy 
does not recognise teenagers who become parents before the required age at marriage. Such teenagers miss out on most state-sponsored social programs. An interview session with the head of the RDP program in the municipal council did not commit himeslef if there is any social legislation which takes into account the housing welfare of single tennage mothers. He reported:

'As far as I know, the legislation which can offer opportunities for teenage mothers to have rights of allocation of housing un the 'scheme' is in its conclusion stage and sooner than later, the government will have a framework which can take teenager mothers into account'.

The proportion of low- cost rentals units, shrunk by 13\% between 1993 and 2003. This has been due to loss of older and lower quality apartments in the private market (Kok et al., 2010). About $40 \%$ of households in 2005, showed children with age's birth through 17 reporting the following housing problems; physically inadequate housing, crowded housing, cost burden association. When a household spends 30\% more on his annual income for housing, then this is termed as a burden (Makiwane et al., 2010). Even before the current housing crisis, unmet needs for decent and affordable rental housing have been increasing. Based on the inherent housing challenges, most poor households who bring up children in informal settlements famously known as 'slums' like in Soweto, end up losing those children to the streets since they cannot afford the basic needs other than the indecent housing(Skinner, 2006).

Economic insecurity: More than $60 \%$ of families in 2005 with an income of less than $30 \%$, were paying more than half of their income for rent which was approximately the same percentage living in inadequate housing. The increase of homeless families is then contributed by lack of affordable rental housing and current economic recession. Due to unemployment and low income rates for blue collar jobs, makes this families vulnerable. Majority of homeless children are from single mothers who depended mostly on public support and unable to meet the needs of this children(Makiwane et al., 2010).

Violence at home: one of the major factors that cause homelessness is the status of violence at their homes. More than $80 \%$ of homeless mothers with children experience domestic violence (O. Olufemi, 2008). Characteristics such as traumatic experiences are mostly found in women with children in homeless shelters and domestic violence shelters. Instability in housing is mostly as a result of intimate partner violence. Witnessing violence or sexual abuse are some of the experiences by children who run away from home. An interview session with one of the victims confirmed that most of the victims try to run away from home due to chronic cases of violence ochstrated by differences among parents or violence metted on them by the parents. One of the violence victim in the home reported:

'I have gone through a lot at home. My dad is very abusive, and I havv ewitnessed fights and disagreements which made me to leave to this place because I was scared of my life'

This clearly indicates that violence at home is amajor causative factor which makes many children to leave their homes for the streets or street homes.

Lack of positive social support: most children who are homeless suffer from unstable social support. This is because they usually have fewer social networks and less social support (O. J. E. Olufemi \& Urbanization, 1998). Children who are homeless report friends as a source of support rather than from their family members(Parks et al., 2007). 
Involvement in the child welfare system: children who are under foster care are at a higher risk of being homeless. Approximately $49 \%$ of children in foster families have reported a history of running away from home

\subsection{Social Legislation and Rehabilitation}

In social legislation and rehabilitation a strategic action plan on homelessness is required. In South Africa the goals include preventing episodes of homelessness including individuals and families. Some of the actions taken are; to identify risks and protective factors to prevent this episodes, developing, testing, disseminating and promoting the use of evidence based homelessness prevention and early intervention programs and strategies.

\subsection{Housing Policy for the Homeless}

The RDP programme seems not to benefit majority of the ever rising poor population in South Africa. Besides that, the RDP housing scheme benefits newly married poor couples with no jobs or source of income at the initial stages of their union when they have few children. As the family size rise, the size of the house allocated through the RDP programme is not sufficient for the family (Huchzermeyer, 2001). The government led by Nelson Mandela inherited unenviable housing record as a legacy of apartheid and its protracted demise. South Africa had underperformed in terms of housing provision for a number of decades considering it being a middle income country (Seager \& Tamasane, 2010). The constitution in South Africa contains three sub-sections relating to housing. The relevant section include section 26 (1) stating that everyone has the right to have access to adequate housing and section 26(2) which states that the state must take reasonable legislative and other measures, within its available resources, in order to achieve progressive realization of its rights.

\subsection{Rehabilitation Framework and Plight of Street Children}

According to research by scholars on the rehabilitation schemes initiated by the state in South Africa, treatment of children in the criminal justice system and street children rights, emphasize on rehabilitation of homeless children. The framework works in the sense that the state picks the street children and the homeless children and admits them in shelter homes which are funded by the state. In this home the children only attend schools up to grade 12 and even those who reach this level are not sure of proceeding beyond that level. Those who pass the matriculation examinations are admitted to secondary schools and awarded bursaries to access quality secondary education while still in the home. Upon reaching eighteen years, the children are supposed to exit the homes and go start life or be integrated to the families(Makiwane et al., 2010). One major issue with this framework is that the children are not empowered and psychologically prepared to be aware that at that age they will leave the homes and go start life on their own. Therefore, by the time they are sent out of the homes, they become desperate and resort back to the streets. Those who survive are the ones who excel in their academic as they have chances of proceeding with their further education. This is to integrate them and make them become productive members of the society. Due to the fact that these children are seen as becoming as opposed to being makes it difficult for the society to create interest in integrating them in their current situation (Wakhweya, Dirks, \& Yeboah, 2008). 
Most frameworks for rehabilitation can however sometimes be ineffective and mostly detrimental to the well- being of the child. Identifying the immediate need and problems of the homeless children is usually the best approach towards a successful rehabilitation framework. Ward and Seager (2010), states that rehabilitation process of street children is a tasking process that requires involvement of various stakeholders for it to be a success. The plight of street children and life are studies that have been done on street children but little has been done on rehabilitation process and success of objectives. Rehabilitation centres or shelter homes are not only ways of incorporating homeless children in the society. Other avenues like adoptions, working for families, juvenile homes, orphanages, church institutions and rescue children homes are some of the ways to help homeless children(Asante, Meyer-Weitz, \& Petersen, 2014).

\section{Challenges Faced by the Street Children in Their Shelter Homes in South Africa}

There are several challenges facing street children especially those in shelter homes in South Africa. This is against the backdrop of aspiration by the national and provincial government in South Africa of ensuring sustainable rehabilitation of street families.

\subsection{Lack of Food and Appropriate Infrastructure}

Most of the shelter homes do not have enough funds and this makes it difficult for them to provide enough diet food. Children in this homes often lack food which is dietary and even at times end up Sharing between two to survive or others staying the day long without any food. (Maillot, Million, Wei, Gauthier, \& Taché, 2000). Cross et al. (2010), states that, most shelter homes depend on donations to obtain some of this basic need and feed the children that they have rescued from the street. Due to lack of money then it's difficult for this homes to buy food on a daily basis. Lack of food and feeding habits of these children may generally expose them to food borne infectious diseases like diarrheal diseases. Shelter is a basic need for any human kind. Shelters in South Africa are mostly run by private institutions. Those run by the government are few and poorly structured with unfavourable conditions to house this children (Du Toit, 2010). This infrastructures' are prone to natural disasters which is a danger to the children in this home (Maillot et al., 2000).

\subsection{Education Transition}

Education is a right even to the street children, this right is usually denied by most school systems which do not accommodate this highly vulnerable group. Transitioning for the street children to education is difficult due to a variety of barriers that this children face. Since this children need to work to support themselves then it becomes a challenge for them to attend school. very few children in shelter homes attend secondary education and only a small number acquire vocational training (Naidoo, 2010). Shelters return most children to school which is a tedious process since some suffer from shame and low self-esteem. The teachers' incompetence in dealing with street children has also caused the transition to be hard. Negative labelling and poor awareness in the community and need for reintegration is a big barrier to education transition of the street children.

\subsection{Health of the Street Children}

Street children way of life exposes them to health problems. Being attracted to waste which includes that of the health centres, they are highly vulnerable to health problems. Health 
diseases like skin diseases, coughs and colds, stomach ulcers, diarrheal, STDs, malnutrition etc are some of the health diseases they experience. In studies conducted in South Africa on street children, they expressed health problem as being the biggest and recurrent problem (Seager \& Tamasane, 2010). Use of drug substances and exposure to other hazards increases children's vulnerability to health problems. Vulnerability to sexually transmitted diseases is also high due to early experiences of sex (Seager \& Tamasane, 2010). Lack of awareness programmes and treatment facilities by the government is a great challenge for street children who face viral, bacterial and even fungal health problems. Shelter homes act in a big role to ensure the health issues of this children are dealt with. When the street children arrive in this homes they are assed of any medical condition that they may be having. It is a challenge to this shelter homes since most of them do not have enough infrastructure to take care of this children.

\subsection{Rehabilitation Transition}

Rehabilitation transition challenges occur in rehabilitation centres and those the children face during rehabilitation. Children from the streets are vulnerable to infectious diseases and some of them when they are taken to this centres they are diagnosed with this diseases which become very expensive for rehabilitation centre's to manage financially. Makiwane et al. (2010), stated that most rehabilitation institutions find solutions for children living in the streets to be predominantly in residential settings, a school, an orphanage or reformatory. These children find themselves as virtual prisoners closed in an environment. When they are enclosed in these places then their social and emotional skills are uncultivated making it impossible to develop their human potentials(Hills et al., 2016). This rehabilitation centres are also not cost effective and they only take a limited number of children who they rescue from the streets. Some rescued children from the street in rehabilitation centres also suffer from frequent beatings, ill treatment as they are seen as delinquents and even rape from the adults and older street children. These then become a challenge in retaining this children in the institution since they suffer from fear. Naidoo (2010), expresses that schools find it difficult to cope with children under rehabilitation due to limited resources and untrained personnel to deal with schooling street children.

\subsection{Family Involvement in the Rehabilitation Process}

One major issue of the rehabilitation framework is the role of the parents or community in the rehabilitation process. The role of the social workers is to asses which children are in vulnerable situation that need protection. As such, they take them from the streets and admit them in homes. The social workers also rescue children who are suffering in poor families and take them for admission into shelter homes (Huchzermeyer, 2001). However, the moment the children are admitted in shelter homes, the parental involvement in visiting the children in the shelter homes stops as the children are abandoned in the homes with minimal parental involvement in the upbringing of the kids. This has posed a great $\mathrm{c}$ challenge to the children especially after their 12 grade examinations and after attaining the mandatory age of exiting from the shelter homes since majority have lost touch with their families. Therefore they resort to reporting back to the streets (Skinner, 2006). 


\section{Discussions and Recommendations}

Shelters and rehabilitation centres are very important and fundamental in mitigating the plight of children who are homeless and live in the streets. This children desire care and protection from this centres and potentially a quality life. Several policies entrance the rights and welfare of children irrespective of their background. Framework in the UN Charter on human rights and the African Charter on the rights and welfare of the child as well as in other national instruments such as Children's Act 2001 are basic laws in many countries. Rehabilitation programmes are very important in keeping children living on the streets off the streets and promoting their social integration and rehabilitating and reform them through various programs (Ward \& Seager, 2010). In South Africa the plight of children living on the streets is still largely unabated due to characteristics unkempt presences in the streets. Proactive action is then a call for engagements with different stakeholders to formulate policies and action plans for rehabilitation and reintegration and enforcement of this policies. Most of rehabilitation centres in South Africa had constraints in lack of funds, inadequate rehabilitation staff, and inability to cope with programmed activities especially the drug addicts.

\section{Recommendations}

One of the major recommendations of the shelter programme to rehabilitate street children and the homeless is that the government should adopt a more pro-active and sustainable approach in rehabilitating street children. Strategies of integrating the children back to the society or families after spending several years in the homes must take into account the fact that most of children either became parents while in the homes or grown-ups whose needs have changed and as such they need to be enrolled in a special empowerment programs. Secondly, while in the shelter homes, the children should be separated based on gender and age. The study revealed that majority of the students are abused by the fellow peers and little is done in protecting them against such atrocities. Thirdly, Shelter homes should upgrade their programmes to better standards which should enable these centres to handle these children irrespective of their background and special challenges. The government should allow children who are already in shelters to acquire education freely.

A flexible curriculum should be discussed on by the relevant stakeholders which should be flexible to accommodate those who have been in the streets for the better part of their lives. Some of this children may have forgotten even how to write and hence require a tactical approach when introduced to education again. Integration frameworks and strategies should be implemented by the government to ensure acceptance and self-awareness and building self-esteem in these children. Due to addiction and prostitution which is a common occurrence for street children then it is necessary to study the immediate conditions of the street children before they are taken to their rehabilitation centres. Support should be enhanced by providing individuals who are readily available in the community with whom the children discuss their concerns, possibly at a shelter. Having support and someone to listen is necessary for any developing adolescent. Informing the children about what is already available in the area is also necessary. Lastly, Drug and alcohol counseling and education on the causes and effects of drug use should be available in the hope that the children would desist from further use. The phenomenon of street children and shelters for 
them is not a new thing in the South African community. It is then the government and the community's responsibility to make new frameworks and strategies to ensure that the process and programmes undertaken in rehabilitation are a success.

\section{References}

Arnold, E. M., \& Rotheram-Borus, M. J. (2009). Comparisons of prevention programs for homeless youth. Prev Sci, 10(1), 76-86. https://doi.org/10.1007/s11121-008-0119-4

Asante, K. O., Meyer-Weitz, A., \& Petersen, I. (2014). Substance use and risky sexual behaviours among street connected children and youth in Accra, Ghana. Substance abuse treatment, prevention, and policy, 9(1), 45. https://doi.org/10.1186/1747-597X-9-45

Cluver, L., \& Gardner, F. (2007). Risk and protective factors for psychological well-being of children orphaned by AIDS in Cape Town: a qualitative study of children and caregivers' perspectives. AIDS Care, 19(3), 318-325. https://doi.org/10.1080/09540120600986578

Cross, C., Seager, J., Erasmus, J., Ward, C., \& O'Donovan, M. J. D. S. A. (2010). Skeletons at the feast: A review of street homelessness in South Africa and other world regions. Development Southern Africa, 27(1), 5-20. https://doi.org/10.1080/03768350903519291

Cross, C., \& Seager, J. R. J. D. S. A. (2010). Towards identifying the causes of South Africa's street homelessness: Some policy recommendations. Development Southern Africa, 27(1), 143-158. https://doi.org/10.1080/03768350903519416

Cumber, S. N., \& Tsoka-Gwegweni, J. M. (2015). The health profile of street children in Africa: a literature review. Journal of public health in Africa, 6(2). https://doi.org/10.4081/ jphia.2015.566

Du Toit, J. L. J. D. S. A. (2010). Local metropolitan government responses to homelessness in South Africa. Development Southern Africa, 27(1), 111-128. https://doi.org/10.1080/ 03768350903519390

Hills, F., Meyer-Weitz, A., \& Asante, K. O. (2016). The lived experiences of street children in Durban, South Africa: violence, substance use, and resilience. International Journal of Qualitative Studies on Health And Well-being, 11(1), 30302. https://doi.org/10.3402/qhw.v11. 30302

Huchzermeyer, M. (2001). Housing for the poor? Negotiated housing policy in South Africa. Habitat International, 25(3), 303-331. https://doi.org/10.1016/S0197-3975(00)00037-0

Kok, P., Cross, C., \& Roux, N. J. D. S. A. (2010). Towards a demographic profile of the street homeless in South Africa. 27(1), 21-37. https://doi.org/10.1080/03768350903519309

Maillot, C., Million, M., Wei, J. Y., Gauthier, A., \& Taché, Y. (2000). Peripheral corticotropin-releasing factor and stress-stimulated colonic motor activity involve type 1 receptor in rats. Gastroenterology, 119(6), 1569-1579. https://doi.org/10.1053/gast.2000. 20251

Makiwane, M., Tamasane, T., \& Schneider, M. J. D. S. A. (2010). Homeless individuals, families and communities: The societal origins of homelessness. Development Southern Africa, 27(1), 39-49. https://doi.org/10.1080/03768350903519325 


\section{Macrothink}

International Journal of Social Work

ISSN 2332-7278

2019, Vol. 6, No. 2

Malindi, M. J. (2014). Exploring the roots of resilience among female street-involved children in South Africa. Journal of Psychology, 5(1), 35-45. https://doi.org/10.1080/ 09764224.2014 .11885503

Mukorombindo, Y. C. (2012). Social networks in recently established human settlements in Grahamstown East/Rhini, South Africa. Rhodes University.

Naidoo, V. J. D. S. A. (2010). Government responses to street homelessness in South Africa. Development Southern Africa, 27(1), 129-141. https://doi.org/10.1080/03768350903519408

Olufemi, O. (2008). Experiential and emotional encounters of women planners in Africa. Development in Practice, 18(3), 412-419. https://doi.org/10.1080/09614520802030532

Olufemi, O. J. E., \& Urbanization. (1998). Street homelessness in Johannesburg inner-city: a preliminary survey. Environment and Urbanization, 10(2), 223-234. https://doi.org/10.1177/ 095624789801000210

Parks, R. W., Stevens, R. J., \& Spence, S. A. J. J. O. T. R. S. O. M. (2007). A systematic review of cognition in homeless children and adolescents. Journal of the Royal Society of Medicine, 100(1), 46-50. https://doi.org/10.1177/014107680710000116

Seager, J. R., \& Tamasane, T. J. D. S. A. (2010). Health and well-being of the homeless in South African cities and towns. Development Southern Africa, 27(1), 63-83. https://doi.org/10.1080/03768350903519358

Skinner, D. (2006). A situational analysis of orphans and vulnerable children in four districts of South Africa: HSRC Press.

Wakhweya, A., Dirks, R., \& Yeboah, K. (2008). Children thrive in families: Family-centred models of care and support for orphans and other vulnerable children affected by HIV and AIDS. AIDS JLICA.

Ward, C. L., \& Seager, J. R. J. D. S. A. (2010). South African street children: a survey and recommendations for services. Development Southern Africa, 27(1), 85-100. https://doi.org/10.1080/03768350903519374

\section{Copyright Disclaimer}

Copyright reserved by the author(s).

This article is an open-access article distributed under the terms and conditions of the Creative Commons Attribution license (http://creativecommons.org/licenses/by/3.0/). 